\title{
Assessing Civic Education as Instrument for Building True Democratic Structures Among Students of Tertiary Institutions in Ogun State
}

\author{
A.A. Adediran, J.O. Atanda and F.F. Oguntayo \\ Social Studies Department, School of Arts and Social Sciences, Federal College of Education, Abeokuta, Ogun State \\ Corresponding author: speaktoa3@yahoo.com
}

Received: 12 Jan., 2019

Revised: 17 Feb., 2020

Accepted: 20 March, 2020

\begin{abstract}
This research work investigated on the assessing civic education as instrument for building true democratic structures among students of tertiary institutions in Ogun State. This study adopted a descriptive research survey design. The population comprised of all the students in Higher Institutions in Ogun State. Simple random sampling techniques was used for this study and sample of two hundred (200) students were selected from four (4) Higher Institutions in Ogun State. Fifty (50) students were selected from each school for the purpose of this research work. Questionnaire was the instrument used to elicit information required from the respondents. Four (4) null hypotheses were formulated to guide the study. The data collected was analyzed using Chi-square statistics tools however, the findings indicated that: there will be significant effect on the level of Civil Education as instrument for Building True Democratic Structures among Students of Tertiary Institutions; the role of Civic education will significantly serve as instrument for building true democratic structures among students of tertiary institutions in Ogun State; there will be significant relationship between Civic Education and true democratic structures among students of tertiary Institutions in Ogun State and there will be significant relationship between knowledge of Civic Education and creating awareness on the building of true democratic structures among students of Tertiary Institutions in Ogun State. However, it was discovered that all the constructed hypotheses were rejected. Therefore, it was recommended that: Civic Education Curriculum contents should be strengthened to be seen as a catalyst for the advancement of individual and national development in order to ensure true democratic system in Nigeria and socio-civic and political education should not be limited to the school system. Hence, both formal and informal approaches should be adopted to orientate the citizens on the need for active participation in the political system and proactive civic engagement.
\end{abstract}

Keywords: Civic Education, Assessing, Instrument Building Structures, Democratic 
Traditionally, civic education efforts have raised high expectations. It is assumed that civic education will help prepare adolescents for their future role as citizens in a democratic society (Galston, 2004; Torney-Purta, 2002). As a result of growing social and academic concerns about the vitality of civic culture in Western democracies, various countries and education systems have stepped up their civic education efforts in recent years (Pasek, Feldman, Romer and Jamieson, 2008). Current research, however, provides little information about the effects of these efforts, and skeptics would argue that increased civic education efforts have apparently not turned the tide of declining political participation levels among young age groups (Malin, 2011). It therefore remains to be investigated whether these efforts actually contribute to the development of democratic attitudes and behaviours and, more specifically, which educational practices can be expected to have an effect on specific outcomes.

The available research on the effects of civic education suffers from a number of problems and shortcomings. It has to be noted that civic education itself has changed dramatically over the past decades. While past efforts focused on cognitive effects and on cultivating patriotism among pupils, the scope of civic education has been vastly expanded in recent decades (Sapiro, 2004). It has been emphasized that schools themselves should function as a democratic community (Campbell, 2008), while service learning has been introduced or reinforced in order to promote active citizenship (Hart, Donnelly, Youniss \& Atkins, 2007). The existing research literature, however, does not allow us to identify the most effective practice for engendering civic identity among adolescents and young adults. The explicit goal of the current study is to compare the effects of these different forms of civic education.

It is essential for citizens in a democratic polity to have sufficient knowledge of Constitutional principles as well as the structure, function, and process of government, knowledge of how the system works provides a basis for the development of a sense of political efficacy and civic duty that facilities participation (Delli and Keeter, 1996).Studies have demonstrated that higher levels of political knowledge are associated with greater acceptance of democratic principles, issue understanding, voting and engagement in community affairs (Galston, 2001). Despite its importance for democratic engagement, Americans' political knowledge has remained at virtually the same low levels for more than half a century (Pew Research Center, 2011).

Structure is an arrangement and organization of interrelated elements in a material object or system, or the object or system so organized. Democratic structures are designed specifically to provide opportunities for members to be involved and to directly participate in determining the policies, activities and direction of the democratic. It is a system of government where the citizens exercise power by voting. In a direct democracy, the citizens as a whole form a governing body and vote directly on each issue. In a representative democracy the citizens elect representatives from among themselves. Democracy is a system of processing conflicts in which outcomes depend on what participants do, but no single force controls what occurs and its struggle repeatedly to realize their interests and devolves power from groups of people of people to sets of rules (Przeworski, 1991). A true democracy is to provide equal opportunities for members of a particular group to be involved and to directly participate in determining the policies, activities and direction of the democratic especially during election. 
Civic education programmes have the potential to convey political knowledge to students. However, the extent to which knowledge is gained through these programmes depends upon students' civic learning experience. Civic instruction across the nation varies widely in its structure, content and quality. Many schools incorporate civic education into social studies or American history courses rather than offering dedicated civics classes (Youniss, 2011). At the same time, school based programs that aim to improve civics instruction by going beyond standard lecture and textbook teaching methods alone have been implemented. Students not only learn about the constitutional and historical foundations of American government, the requirements of citizenship, and structure and functions of the political system, they also become familiar with the skills needed for meaningful political and civic participation, such as public speaking, participating in public hearings, contacting officials, meeting with community leaders about issues, and using media to engage the polity (Kahne, and Westheimer, 2006; Quintelier, 2010). Therefore, these kinds of active learning experiences can provide a memorable context for understanding facts about government and politics, and reinforce information that is gained through standard textbook and lecture formats. However, based on this perspective this research work will be critical examine on the employing civic education as instrument for building true democratic structures among students of Tertiary Institutions in Ogun State.

Despite several interventions aimed at curtailing social menace and attitudinal flaws, it seems, Nigeria citizenry still lacks the necessary civic competence. Indeed, immorality, incivility, political violence, ethno-religious crises and other social vices are on the increase among the citizens. The reason for the flaws has been partly adduced by several studies to non-involvement of individual in political and community engagement for promotion of civic competence. Researchers have revealed many factors which affect civic competence, among which are political participation, mass media campaigns, social welfarism, community engagement and environmental values. Specifically, political participation and community engagement have been viewed as symbiotic platforms for citizens to perform their civic duties and political obligations. However, without gainsaying the term education will definitely play a key role in democratic structure and equips one with knowledgeable skills necessary for building a true democratic structure among its citizenship etc. Based on this issue the research work therefore tends to critically examine the employment of civic education as instrument for building true democratic structures among students of Tertiary Institutions in Ogun State.

\section{Objectives of the Study}

The objectives of this study are to:

Examine the level of Civic education as instrument for building true democratic structures among Students of Tertiary Institutions in Ogun State.

Investigate the role of Civic education as instrument for building true democratic structures among Students of Tertiary Institutions in Ogun State.

Examine if there is significant relationship between Civic Education and true democratic structures among Students of Tertiary Institutions in Ogun State. 
Investigate the relationship between knowledge of Civic Education and creating awareness on the building of true democratic structures among Students of Tertiary Institutions in Ogun State.

\section{Research Hypotheses}

1. There will be no significant effect on the level of civil education as instrument for building true democratic structures among students of Tertiary Institutions.

2. The role of Civic education will not significantly serve as instrument for building true democratic structures among Students of Tertiary Institutions in Ogun State.

3. There will be no significant relationship between Civic Education and true democratic structure among Students of Tertiary Institutions in Ogun State.

4. There will not be significant relationship between knowledge of Civic Education and creating awareness on the building of true democratic structures among Students of Tertiary Institutions in Ogun State.

\section{Methodology}

The descriptive survey design was used in carrying out the research study, this research design was considered most appropriate because it provides wider scope for obtaining information needed for the purpose of the study. The population for this study consists of all Students selected in Four (4) Higher Institution in Ogun State. The total sample for the study comprises of all students in four (4) selected higher institutions in Ogun State. The multistage, sampling procedure was adopted for the selection of the sample.

Stage 1: Stratified random sampling techniques was used to select four (4) Higher Institutions in Ogun State.

Step 2: The sampling techniques employed in the cause of this research is the stratified random sampling techniques, for 50 students from each of the four (4) selected Higher Institutions making Two Hundred in all four Higher Institutions. The Schools are as follows:

1. Federal College of Education, Abeokuta.

2. Lagos State University (Federal College of Education, Abeokuta) Centre.

3. University of Ibadan Federal College of Education, Abeokuta) Centre.

4. Federal University of Agriculture, Abeokuta (FUNAAB).

The instrumentation used for the research work is a questionnaire. Hence, the researcher makes use of questionnaire which has designed as a potent instrument for data collection. Thus, sixteen (16) questions items were designed for all respondents to elicit response from the. The questionnaire was of two (2) 
selections. The Section "A" part of the questionnaire consist of the respondent bio-data such as Name, Sex, Age, Class, School while the Section "B" part consist of a structural questions which requires that respondent pick from options of their best choice. The section however, ranges from Strongly Agree, Agree, Disagree and Strongly Disagree.

The questionnaire draft was given to supervisor for corrections, certification to make sure they contain relevant and adequate information for the study. Reliability concern the students to which a particular procedure gives similar result over a number of repeated trials (Orodho, 2009). The instruments in the category were the same for piloting and actual study from four (4) selected Higher Instructions in Ogun State.

The major statistical test used in analyzing the data collected for the study was simple percentage for the demographics data while Chi-square statistical tools was used to test the accuracy of the hypotheses used at 0.05 level of significance.

\section{Presentation of Data Analysis and Result}

The data analyzed are based on the information collected from students from four (4) selected Higher Institutions in Ogun State using a research instrument (questionnaire) for the data collection and Chisquare statistical tools was used to test the hypotheses.

\section{Testing of Hypotheses}

Hypothesis 1: There will be no significant effect on the level of civil education as instrument for building true democratic structures among Students of Tertiary Institutions.

Table 1: Contingency Table on the level of Civil Education as instrument for Building True Democratic Structures

\begin{tabular}{|c|c|c|c|c|c|c|}
\hline Respondents & $\mathbf{N}$ & Cal. Value $\left(\mathrm{X}^{2}\right)$ & d.f & Tab. Value $\left(X^{2}\right)$ & Level of Significant & Decision \\
\hline 139 & \multirow{3}{*}{200} & \multirow{3}{*}{31.2} & \multirow{3}{*}{3} & \multirow{3}{*}{7.812} & \multirow{3}{*}{0.05} & \multirow{3}{*}{ REJECTED } \\
\hline 61 & & & & & & \\
\hline 200 & & & & & & \\
\hline
\end{tabular}

Table 1 shows that the calculated chi-square value of 31.2 at a degree of freedom of 3 is greater than the critical value of 7.812 at 0.05 alpha level of significance. Hence, the null hypothesis which states that there will be no significant effect on the level of Civil Education as instrument for Building True Democratic Structures among Students of Tertiary Institutions was rejected. This implies that there will be significant effect on the level of Civil Education as instrument for Building True Democratic Structures among Students of Tertiary Institutions.

Hypothesis 2: The role of Civil education will not significantly serve as instrument for building true democratic structures among Students of Tertiary Institutions in Ogun State. 
Table 2: Contingency table on the role of Civic Education for Building True Democratic Structure

\begin{tabular}{|c|c|c|c|c|c|c|}
\hline Respondents & $\mathbf{N}$ & Cal. Value $\left(\mathbf{X}^{2}\right)$ & d.f & Tab. Value $\left(\mathrm{X}^{2}\right)$ & Level of Significant & Decision \\
\hline 127 & \multirow{3}{*}{200} & \multirow{3}{*}{27.4} & \multirow{3}{*}{3} & \multirow{3}{*}{7.812} & \multirow{3}{*}{0.05} & \multirow{3}{*}{ REJECTED } \\
\hline 73 & & & & & & \\
\hline 200 & & & & & & \\
\hline
\end{tabular}

Table 2 indicates that the calculated chi-square value of 27.4 at a degree of freedom of 3 is greater that the critical value of 7.812 at 0.05 alpha level of significance. Hence, the null hypothesis which states that the role of Civic education will not significantly serve as instrument for building true democratic structures among Students of Tertiary Institutions in Ogun State was rejected. This implies that the role of Civic education will significantly serve as instrument for building true democratic structures among Students of Tertiary Institutions in Ogun State.

Hypothesis 3: There will be no significant relationship between Civic Education and true democratic structures among students of Tertiary Institutions in Ogun State.

Table 3: Contingency table on the relationship between Civic Education and True Democratic Structure

\begin{tabular}{|c|c|c|c|c|c|c|}
\hline Respondents & $\mathbf{N}$ & Cal. Value $\left(\mathrm{X}^{2}\right)$ & d.f & Tab. Value $\left(\mathrm{X}^{2}\right)$ & Level of Significant & Decision \\
\hline 122 & \multirow{3}{*}{200} & \multirow[t]{3}{*}{27.4} & \multirow{3}{*}{3} & \multirow{3}{*}{7.812} & \multirow{3}{*}{0.05} & \multirow{3}{*}{ REJECTED } \\
\hline 73 & & & & & & \\
\hline 200 & & & & & & \\
\hline
\end{tabular}

Table 3 indicates that the calculated chi-square value of 28.2 at a degree of freedom of 3 is greater that the critical value of 7.812 at 0.05 alpha level of significance. Hence, the null hypothesis which states that there will be no significant relationship between Civic Education and true democratic structures among Students of Tertiary Institutions in Ogun State was rejected. This implies that there will be significant relationship between Civic Education and true democratic structures among Students of Tertiary Institutions in Ogun State.

Hypothesis 4: There will not be significant relationship between knowledge of Civic Education and creating awareness on the building of true democratic structures among students of tertiary institution is Ogun State.

Table 4: Contingency table on the relationship between knowledge of Civic Education and creating awareness on the building of true democratic structures

\begin{tabular}{|c|c|c|c|c|c|c|}
\hline Respondents & $\mathbf{N}$ & Cal. Value $\left(X^{2}\right)$ & d.f & $\begin{array}{c}\text { Tab. Value } \\
\left(\mathrm{X}^{2}\right)\end{array}$ & $\begin{array}{c}\text { Level of } \\
\text { Significant }\end{array}$ & Decision \\
\hline 111 & \multirow{3}{*}{200} & \multirow[t]{3}{*}{36.1} & \multirow{3}{*}{3} & \multirow{3}{*}{7.812} & \multirow{3}{*}{0.05} & \multirow{3}{*}{ REJECTED } \\
\hline 89 & & & & & & \\
\hline 200 & & & & & & \\
\hline
\end{tabular}


Table 4 indicates that the calculated chi-square values of 36.1 at a degree of freedom of 3 is greater than the critical value of 7.812 at 0.05 alpha level of significance. Hence, the null hypothesis which states that there will not be significant relationship between knowledge of Civic Education and creating awareness on the building of true democratic structures among Students of Tertiary Institutions in Ogun State was rejected. This implies that there will be significant relationship between knowledge of Civic Education and creating awareness on the building of true democratic structures among Students of Tertiary Institutions in Ogun State.

\section{Discussion of Findings}

In research hypothesis one which states that there will be no significant effect on the level of Civic Education as instrument for Building True Democratic Structures among Students of Tertiary Institutions was rejected thus: It was indicated that there will be significant effect on the level of Civic Education as instrument for Building True Democratic Structures among students of tertiary institutions. This statement was in line according to Olaitan (2007) affirmed that civic education remains an important means of teaching the populace about individual rights and what duties and responsibilities the governed and leaders should do. The introduction of Civic Education as a subject to be taught in primary and secondary schools in Nigeria is expected to further deepen democratic culture and encourage qualitative participation of the average Nigerian in the government process. The Civic Education curriculum according to Yahya (2013) addresses young Nigerians in the formative educational years. The contents address issues that are important to developing young Nigerian people into responsible citizens. In other words, the curriculum of civic education enables our young people imbibe the values, norms, knowledge, actions and activities for sustaining development of building true democratic structure.

Civic education is one of the subjects taught in both primary and secondary schools which inculcates sound moral values in the youths. It is the subject which aims to help people learn how to become active, informed and responsible citizens. Civic education remains an important means of teaching the populace about individual rights and what duties and responsibilities the leaders and the led have Galston (2004) and Torney-Purta (2002) asserted that civic education efforts have raised high expectations. It is assumed that civic education will help prepare adolescents for their future role as citizens in democratic society. As a result of growing social and academic concerns about the vitality of civic culture in Western democracies, various countries and education systems have stepped up their civic education efforts in recent years (Pasek, Feldman, Romer and Jamieson, 2008).

In research hypothesis two which states that the role of Civic education will not significantly serve as instrument for building true democratic structures among Students of Tertiary Institutions in Ogun State was rejected thus: This implies that the role of Civic education will significantly serve as instrument for building true democratic structures among Students of Tertiary Institutions in Ogun State. This statement was in line according to NERDC (2007) affirmed that enhancing the teaching and learning of emerging issues, promoting the understanding of their inter-relationship between man/woman, the government and the society, to creating awareness on the provision of the Nigerian constitution and the 
need for democracy and to inculcating in students their duties and obligations to society. Structure is an arrangement and organization of interrelated elements in a material object or system, or the object or system so organized. Democratic structures and designed specifically to provide opportunities for members to be involved and to directly participate in determining the policies, activities and direction of the democratic. It is a system of government where the citizens exercise power by voting. In a direct democracy, the citizens as a whole form a governing body and vote directly on each issue. In a representative democracy the citizens elect representatives from among themselves. Democracy is a system of processing conflicts in which outcomes depend on what participants do, but no single force controls which occurs and its outcomes. The uncertainty of outcomes in inherent in democracy. Democracy makes all forces struggle repeatedly to realize their interest and devolves power from groups of people to sets of rules (Przeworski, 1991). A true democracy is to provide equal opportunities for members of a particular group to be involved and to direct participate in determining the policies, activities and direction of the democratic especially during election.

In research hypothesis three which states that there will be no significant relationship between Civic Education and true democratic structures among Students of Tertiary Institutions in Ogun State was rejected. Thus: it was deduced that there will be significant relationship between Civic Education and true democratic structures among Students of Tertiary Institutions in Ogun State. This statement was in line according to Youniss (2011) asserted that Civic Education programmes have the potential to convey political knowledge to students. However, the extent to which knowledge is gained through these programmes depends upon students' civic learning experience. Civics instruction across the nation varies widely in its structure, content, and quality. Many schools incorporate civic education into social studies or American history courses rather than offering dedicated civics classes. At the same time, school based programs that aim to improve civics instruction by going beyond standard lecture and textbook teaching methods alone have been implemented. Students not only learn about the Constitutional and historical foundations of American government, the requirements of citizenship, and structure and functions of the political system, they also become familiar with the skills needed for meaningful political and civic participation, such as public speaking, participating in public hearings, contacting officials, meeting with community leaders about issues, and using media to engage the polity (Kahne and Westheimer, 2006; Quintelier, 2010).

In research hypothesis four which states that there will not be significant relationship between knowledge of Civic Education and creating awareness on the building of true democratic structures among Students of Tertiary Institutions in Ogun State was rejected thus: This implies that there will be significant relationship between knowledge of Civic Education and creating awareness on the building of true democratic structures among students of Tertiary Institutions in Ogun State. This statement was in line according to Etzioni, Berkowitz and Wilcox (1995) asserted that Civic education in building a true democracy, therefore, is-or should be-a prime concern. There is no more important task than the developed of an informed, effective, and responsible citizenry. Democracies are sustained by citizens who have the requisite knowledge, skills, and dispositions. Absent a reasoned commitment on the part of its citizens to the fundamental values and principles of democracy, a free and open society cannot 
succeed. It is imperative, therefore, that educators, policymakers, and members of civil society make the case and ask for the support of civic education from all segments of society and from the widest range of institutions and governments.

Delli, Carpini and Keeter (1996) affirmed that it is essential for citizens in a democratic polity to have sufficient knowledge of constitutional principles as well as the structure, function, and process of government. Knowledge of how the system works provides a basis for the development of sense of political efficacy and civic duty that facilitates participation. Studies have demonstrated that higher levels of political knowledge are associated with greater acceptance of democratic principles, issue understanding, voting, and engagement in community affairs (Galston, 2001). Despite its importance for democratic engagement, Americans' political knowledge has remained at virtually the same low levels for more than half a century (Pew Research Centre, 2011).

\section{CONCLUSION}

Based on the findings and discussion of this study, it was deduced that there will be significant relationship between Civic Education and true democratic structures among Students of Tertiary Institutions in Ogun State. It was also concluded that there will be significant relationship between knowledge of Civic Education and creating awareness on the building of true democratic structures among Students of Tertiary Institutions in Ogun State. According to Olaitan (2007), affirmed that civic education remains an important means of teaching the populace about individual rights and what duties and responsibilities the governed and leaders should do. The introduction of Civic Education as a subject to be taught in primary and secondary schools in Nigeria is expected to further deepen democratic culture and encourage qualitative participation of the average Nigerian in the governance process. The Civic Education curriculum according to Yahya (2013) addresses young Nigerians in the formative educational years. The content address issues that the important to developing young Nigerian people into responsible citizens. In other words, the curriculum of civic education enables our young people imbibe the values, norms, knowledge, action and activities for sustaining development of building true democratic structures.

In addition, Youniss (2011) asserted that Civic education programmes have the potential to convey political knowledge to students. However, the extent to which knowledge is gained through these programmes depends upon students' civic learning experience. Civic instruction across the nation varies widely in its structure, content, and quality. Many schools incorporate civic education into social studies or American history courses rather than offering dedicated civics classes. At the same time, school based programs that aim to improve civics instruction by going beyond standard lecture and textbook teaching methods alone have been implemented. Students not only learn about the constitutional and historical foundations of American government, the requirements of citizenship, and structure and functions of the political system, they also become familiar with the skills needed for meaningful political and civic participation, such as public speaking, participating in public hearings, contacting officials, meeting with community leaders about issues, and using media to engage the polity (Kahne and Westheimer, 2006; Quintelier, 2010). 


\section{Recommendations}

The following are recommendations proffered based on the findings of the study:

1. That, Civic Education should be taught to redefine our national priority in favour of hard-work, diligence, honesty and patriotism.

2. That, Civic Education Curriculum contents should be strengthened to be seen as a catalysts for the advancement of individual and national development in order to ensure true democratic system in Nigeria.

3. That, Socio-civic and political education should not be limited to the school system. Hence, both formal and informal approaches should be adopted to orientate the citizens on the need for active participation in the political system and proactive civic engagement.

4. That, Civic learning should be promoted by all and sundry since it has the capacity to perform its mission of promoting an education culture that stimulate civic competence, critical thinking skills, and proffer solutions to complex socio-economic and political issues of state policies.

5. That, Teaching and learning facilities should be adequately provided in schools so as to motivate and encourage teachers to effectively teach and students learn effectively. This will enable effective impartation of Civic Education contents to the students.

6. That, Equal treatment of students irrespective of gender should be ensured and maintained in Civic Education instructions at all level. This will curtain variation in learning among students of different sex.

7. That rural and urban school should be giving equal access to adequate educational facilities and motivation to enable both benefits Civic Education curriculum contents equally.

8. That, schools should run workshops, seminars inform of awareness on the political attitude on the development of political skills on how to solve conflict among inter-schools and more also between educators (teachers) and the learners (students).

\section{REFERENCES}

1. Adetoro, R.A. and Omiyefa, M.O. 2017. An Assessment of Citizens' level of political participation and civic competence. International Journal of Educational Policy Research and Review, 4(5): 72 -80.

2. Arensmeier, C. 2010. The Democratic Common Sense. Young Swedes' understanding of democracy - Theoretical features and educational incentives. Young, 18(2): $197-222$.

3. Behrouzi, M. 2005. Democracy as the political empowerment of the people: The betrayal of an ideal. Lanham, M. D.: Lexington Books.

4. Borhaug, K. 2008. Educating voters: Political education in Norwegain upper secondary schools. Journal of Curriculum Studies, 40(5): 579 - 600. 
5. Buhari declares June 12 Democracy Day, honours Abiola with GCFR. Punch Newspapers. Retrieved 2018-06-07.

6. Campbell, D.E. 2008. Voice in the Classroom: How an open classroom climate fosters political engagement among Adolescents. Political Behavior, 30(4): 437 - 454.

7. Carens, J.H. 2000, Culture, Citizenship and Community. A Contextual Exploration of Justice as Evenhandedness, Oxford: Oxford University Pres.

8. Carter, L.H. and Elshtain, J.B. 1997. Task force on Civic Education Statement of purpose, P. S. Political Science and Politics (December) 744.

9. Cohen, J. 2002. Deliberation and democratic legitimacy. In D. Estlund (Ed.) Democracy (pp. 8-106). Malden, MA: Blackwell.

10. Cohen, J. 1999. "Changing Paradigms of Citizenship and the Exclusiveness of the Demos" International Sociology, 14(3): $245-268$.

11. Davies, P. and Lundholm, C. 2011. Students' understanding of socio-economic phenomena: Conceptions about the free provisions of goods and services. Journal of Economic Psychology: Research in Economic Psychology and Behavioural Economics, 33(1): 79 - 89.

12. Delli Carpini, M.X. and Keeter, S. 1996. What Americans know about politics and why it matters. New Haven: Yale University Press.

13. Dewee, J. 1927. The public and its problems. London: George Allen and Unwin.

14. Etzioni, A., Berkowitz, M.C. and Wilcox, W.B. 1995. Character Building for a Democratic, Civil Society. Alexandria, VA: Character Education Partnership.

15. Galston, W. 2004. Civic Education and Political participation. PS-political Science and Politics, 37(2): 263-266.

16. Galston, William A. 2001. Political Knowledge, Political Engagement, and Civic Education. Annual Review Political Science, 4: $217-234$.

17. Galston, William A. 2004. Civic Education and Political Participation, I. P. S.: Political Science and Politics, April: $263-266$.

18. Habermas, J. 1995. Three normative demokratimodeller (Three Normative Models of Democracy). In E. O. Eriksen (Ed.) Deliberativ Politikk: demokrati I teori og praksis (Deliberative Politics: Democracy in Theory and Practice) (pp. 30 - 45). Oslo: TANO.

19. Hart, D., Donnelly, T.M., Youniss, J. and Atkins, R. 2007. High school community services as a predictor of Adult Voting and Volunteering. American Educational Research Journal, 44(1): 197 - 219.

20. How first coup still haunts Nigeria 50 years on 2016-01-15. Retrieved 2019-04-29.

21. Kahne, J. and Westheimer, J. 2006. The Limits of Political Efficacy: Educating Citizens for a Democratic Society. PS: Political Science and Politics, 39(2): 289 - 296.

22. Kahne, Joseph and Ellen Middaugh. 2006. Democracy for some: The Civic Opportunity Gap in High Schools. CIRCLE Working Paper 59. http://www.civicyouth.org/PopUps/WP59K.pdf.Accessed August 6, 2011.

23. Kymlicka, W. and Norman, W. 2000. “Citizenship in culturally Diverse Societies: Issues, Contexts, Concepts”. In Citizenship in Diverse Societies, W. Kymlicka, W. Norman (Eds.), Oxford: Oxford University Press, 1-41. 
24. Malin, H. 2011. American Identity Development and Citizenship Education: A Summary of Perspectives and Call for New Research CONCLUSION. Applied Developmental Science, 15 (2): 111 - 116.

25. Moodie, E., Markova, I. and Plichtova, J. 1995. Lav representations of democracy: A study in two cultures. Culture and Psychology, 1: 423 - 453.

26. Munck, G. 2014. What is democracy? A rencoceptualization of the quality of democracy. Democratization, pp. 1-26.

27. Pasek, J., Feldman, L., Romer, D. and Jamieson, K. 2008. Schools as incubators of democratic participation: Building long-term political efficacy with civic education. Applied Developmental Science, 12(1): 26 - 37.

28. Pateman, C. 1970. Participation and democratic theory. Cambridge: Cambridge University Press.

29. Pew Research Center for the People and the Press, 2011. Political Knowledge Update. Research Report, Washington, D. C., March 31. http://pewresarch.org/pubs/1944/politicalnes-quiz-iq-congress-controlobsesity-energy-facebook. Accessed June 6, 2011.

30. Press, Fellow (2019-06-10). "May 29 no longer public holiday". Fellow Press. Retrieved 2019-06-11.

31. Quintelier, E. 2010. The effect of schools on political participation: A multilevel logistic analysis. Research Papers in Education, 25(2): 137-154.

32. Rasch, B.E. 2004. Innledning (Introduction). In B. E. Rasch and K. Midgaard (Eds.), Demokrati: Vilkar og virkninger (Democracy: Conditions and Consequences) $\left(2^{\text {nd }}\right.$ ed. Pp. 11 - 22). Bergen: Fagbokforlaget.

33. Rawls, J. 1972. A Theory of Justice, Oxford: Oxford University Press.

34. Sapiro, V. 2004. Not your parents' political socialization: Introduction for a new generation. Annual Review of Political Science, 7(1): $1-23$.

35. Sigel, R. and Hoskin, M. 1981. The Political ideology and subjective culture: conceptualization and empirical assessment. American Political Science Review, 76: 585 - 602.

36. Torney-Purta, J. 2002. The School's Role in developing Civic Engagement: A Study of Adolescents in Twenty-Eight countries. Applied Developmental Science, 6(4): 203 - 212.

37. Torney-Purta, Judith, 2002. The School's Role in Developing Civic Engagement: A Study of Adolescents in Twentyeight countries, Applied Development Science, 6(4): 202 - 211.

38. Youniss, J. 2011. Civic Education: What schools can do to encourage civic identity and Actions. Applied Developmental Science, 15(2): 98 - 103. 